\title{
Students' academic freedom in African universities and democratic enhancement
}

\author{
Kwadwo Appiagyei-Atua* \\ Associate Professor of Law, University of Ghana, Legon, Accra, Ghana \\ https://orcid.org/0000-0002-3118-2383
}

\begin{abstract}
Summary
This article makes a case for the need to recognise students' right to academic freedom as a necessary and vital component in the academic freedom matrix in addition to that of the university and academics. It seeks to affirm this position by exposing the various categories of rights that students are entitled to enjoy on and off campus. The conclusion reached is that the academic freedom of the three actors (university, academics, students) are indivisible, interdependent and interconnected; and that the suppression of students' right to academic freedom has the consequence of denying them the right to engage democratically on the university campus which could spill over into their involvement in realpolitik in the real world.
\end{abstract}

Key words: academic freedom; students' rights; Kampala Declaration; University of Ghana

\section{Introduction}

Students' right to academic freedom in Africa has been given little attention in the literature and in regional instruments such as the 1990 Kampala Declaration on Intellectual Freedom and Social Responsibility (Kampala Declaration). Where it is addressed, it is done only tangentially, that is, when it coincides with the interests of the university or academics. Subsequently, academic freedom for students on the continent continues to suffer abuse and neglect,

LLB (Hons) (Ghana) BL (Ghana School of Law) LLM (Dalhousie, Canada) DCL (McGill, Canada); kappiagyeiatua@ug.edu.gh. The author is grateful to the European Union for granting the Marie Curie Fellowship which enabled research to be conducted at the University of Lincoln, United Kingdom. 
especially as African universities increasingly submit to pressures to corporatise the university, and where the principal violations no longer are directly by the state but by the university management (against academics and students) and academics (against students).

The analysis is applied to the case of the University of Ghana and the conclusion reached is that this development denies students the right and opportunity to engage democratically and to be involved in university affairs and in the way in which knowledge is produced and shared. When these democratic rights are violated in this way, students graduate from the university with a compromised understanding of democracy and human rights. This compromised understanding subsequently informs their behaviour in their communities, workplaces as well as in politics. In the end, the denial of students' academic freedom is likely to have a negative impact on democratisation in Africa.

The article begins by asking who the recipients of the right to academic freedom are, and discusses why students are sidelined in the process. A matrix is posited that identifies this relationship. A brief historical survey is undertaken to establish the context in which students came to acquire the right to enjoy academic freedom in precolonial Africa, Europe and the United States of America. The discussion then proceeds to an examination of two Africa-made documents on academic freedom, namely, the Dar es Salaam Declaration on Academic Freedom and Social Responsibility of Academics (Dar es Salaam Declaration) and the Kampala Declaration. The 1966 ILO/UNESCO Recommendation Concerning the Status of Teachers (ILO/UNESCO Recommendation) and the 1997 UNESCO Recommendation Concerning the Status of Higher Education Teaching Personnel (1997 UNESCO Recommendation) are further used to determine the extent to which students' right to academic freedom is recognised. This analysis is placed in the context of the relationship between academic freedom and the right to education and the way in which this relationship creates space for democratic enhancement, not only on the campus but in society. In this context, the work analyses how the denial of students' academic freedom affects the development of a democratic culture in society.

The final part of the article involves a practical application of the rights and freedoms enshrined in the documents and the extent to which the law is able to enhance the enjoyment and exercise of these rights and freedoms.

\section{Students in the academic freedom matrix}

Academic freedom has often been defined with the focus and attention on the academic. Thus, for example, according to Sir Edward Boyle, 
[a]cademic freedom means the absence of discriminatory treatment on grounds of race, sex, religion or politics, and the right to teach according to his own conception of fact and truth rather than according to any predetermined orthodoxy. It involves freedom to publish and subject to the proper performance of allotted duties, freedom to pursue whatever personal studies are congenial.

Alongside the academic is the university, as reflected, for example, in Dr TB Davie's classical definition of academic freedom as involving 'four essential freedoms ... [for the university] to determine for itself on academic grounds who may teach, what may be taught, how it shall be taught and who may be admitted to study'. 2

The marginal treatment given to the presence or relevance of students' academic freedom suffers an even greater setback where some scholars go to the extent of refusing any form of recognition to it. Byrne, for example, contends that '[t]he term "academic freedom" should be reserved for those rights necessary for the preservation of the unique functions of the university, particularly the goals of disinterested scholarship and teaching ...

In reaction to the lopsided approach in identifying the actors in the academic freedom equation, Metzger argues as follows: ${ }^{4}$

Undoubtedly, students fit less snugly than teachers into the constitutional history of academic freedom. The question is: do they fit so poorly that they ought to be ignored? In the end, it seems best to conclude that, in the academic freedom club, students qualify as special members ... because to keep them out would be anomalous and impoverishing.

Fuchs adds that '[s]tudent freedom is a traditional accompaniment to faculty freedom as an element of academic freedom in the larger sense'. 5 McFarlane's comment in support is that sometimes students' academic freedom is treated as merely 'the by-product of the protection of the freedom of academics'. ${ }^{6}$

1 Quoted in GR Bozzoli Academic freedom in South Africa: The open universities in South Africa and academic freedom 1957-1974 (1974).

2 A van de Sandt Centlivres et al (Editorial Committee) (1957) 'The Open Universities in South Africa: A statement of a conference of senior scholars from the Universities of the Witwatersrand and Cape Town. Compare R Krüger 'The genesis and scope of academic freedom in the South African Constitution' (2013) 8 Kagisano 5. However, in most cases academic freedom for the university is couched as 'institutional autonomy'.

3 JP Byrne 'A special concern of the First Amendment' (1989) 99 The Yale Law Journal 251 at 262.

4 WP Metzger 'Profession and constitution: Two definitions of academic freedom' (1988) 66 Texas Law Review 1265.

5 RF Fuchs 'Academic Freedom: Its basic philosophy, function and history' in $\mathrm{L}$ Joughin (ed) Academic freedom and tenure: A handbook of the American Association of University Professors (1969) 243-44 (Appendix E).

6 B Macfarlane 'Re-framing student academic freedom: A capability perspective' (2012) 63 Higher Education 720. 
The above analysis, which amounts to denying academic freedom to students, is attributed to a narrow understanding of who the rights holders in the academic freedom equation are. ${ }^{7}$ The Lima Declaration on Academic Freedom and Autonomy of Institutions of Higher Education (Lima Declaration) ${ }^{8}$ fairly grants students pride of place in its definition of academic freedom by using 'academic community' to 'cover all those persons teaching, studying, researching and working at an institution of higher education'. ${ }^{9}$ In essence, academic freedom for the university, academics and students is indivisible, interdependent and interconnected.

As discussed elsewhere, the state is the principal duty bearer in the academic freedom matrix. ${ }^{10}$ It owes duties to three entities: the university, academics and students - in that order. Therefore, as against the state, the rights holders are the academic community. However, in the academic freedom matrix, rights holders are also duty bearers in their relations with the other entities in the matrix. Thus, the university is a duty bearer in its relationship to academics and students who serve as rights holders. Similarly, academics owe duties to students. Therefore, in a cascading fashion, the state owes the greatest proportion of the duties while students enjoy most rights in their relationship with the other entities, including the state.

In light of the above, the article adopts a definition of academic freedom as a freedom carved out for academics, higher education institutions and students to enable access and opportunity to conduct scientific inquiry and disseminate the findings thereof - through teaching, publication and the application of the findings to promote human welfare - within the limits of public order, professional ethics and social responsibility and without restraint or the threat of sanctions by government and other power brokers. ${ }^{11}$

\section{Historical context of academic freedom}

\subsection{Pre-colonial Africa}

Ancient Egypt is considered the cradle of higher education, having

7 G Robinson \& J Moulton 'Academic freedom' in LC Becker \& CB Becker (eds) Encyclopaedia of ethics (2001) 1.

8 Adopted at the 68th General Assembly of World University Service, meeting in Lima, Peru, 6-10 September 1988, the year of the 40th anniversary of the Universal Declaration of Human Rights.

9 Sec 1(b) Lima Declaration (n 8).

10 K Appiagyei-Atua et al 'The capture of institutional autonomy by the political elite and its impact on academic freedom in African universities' (2015) 47 Higher Education Review 48.

11 K Appiagyei-Atua, K Bieter \& T Karran 'The composite theory: An African contribution to the academic freedom discourse' (2015) 31 South African Journal on Human Rights 315. 
established universities in the Per-ankh (House of Light) around 2000 $\mathrm{BCE}^{12}$ and the Biblioteca Alexandrina which attracted international scholars, including those who were recognised as 'scholars in residence' at the libraries which served as important seats of learning. One may further mention Islamic universities which evolved later on in Egypt, such as the Al Azhar which remains in existence today, ${ }^{13}$ and Al Qarawwyin in Morocco. ${ }^{14}$

The existence of academic freedom in these institutions cannot be denied due to its inextricable link to the university. ${ }^{15}$ As noted by Karran, 'the principle of academic freedom [is] an essential prerequisite for such an institution'. ${ }^{16}$ Therefore, as long as the university has existed, so has academic freedom. ${ }^{17}$ In principle, the evolution of academic freedom in Africa did not occur without recognition of students as also possessing some form of academic freedom, such as the freedom to write their own manuscripts and freedom of movement which enabled them to travel to study at these centres of learning or universities. ${ }^{18}$

\subsection{Europe}

In the European context, two types of universities emerged, namely, the universitas scholarium (community of scholars (or students) in Bologna and universitas magistrorum et scholarium (community of teachers and scholars) in Paris. Both were formed under the sponsorship of the medieval church and under its authority, with faculties composed mainly of clerics. ${ }^{19}$

According to Neave, two basic types of academic freedom emerged in Bologna and Paris. In Bologna autonomy vested in students who

12 Y G-M Lulat $A$ history of African higher education from antiquity to the present (2005). The per-ankh was an institution devoted to the teaching of both theoretical and practical arts, such as sculpture and other crafts. Lulat also writes that it is thought that some of the Pharaohs studied there, singling out Ramses IV, 'a literary person of considerable knowledge'.

13 Founded in 970 or 972 by the Fatimids as a centre of Islamic learning, its students studied the Qur'an and Islamic law in detail, along with logic, grammar, rhetoric, and how to calculate the lunar phases of the moon. It was one of the first universities in the world and the only one to survive as a modern university to include secular subjects in the curriculum.

14 S Hamdun \& N King (eds) Ibn battuta in black Africa (1975) 52-53.

15 For a discussion on the theoretical origins of the concept, see KD Beiter 'The doctrinal place of the right to academic freedom under the UN Covenants on Human Rights' in (2011) University Values 5-7; A de Baets 'The doctrinal place of the right to academic freedom under the UN Covenants on human rights: A rejoinder' (2012) University Values 2-3; K Appiagyei-Atua 'The theoretical origins of academic freedom' (2014) University Values 5-7.

16 T Karran 'Academic freedom in Europe: Reviewing UNESCO's recommendation' (2009) 57 British Journal of Educational Studies 3.

17 R Quinn 'Defending "dangerous' minds"' (2004) 5 Items and Issues 1.

18 Lulat (n 19).

19 W Rüegg 'The university as a European institution' in $\mathrm{H}$ de Ridder-Symoens A history of the university in Europe Volume 1 Universities in the Middle Ages" Part of A history of the university in Europe (2003) xix. 
hired the professors and also elected the rector. Karran notes that in the examination of candidates for degrees, the authority of the masters was paramount, but in all other matters the students reigned supreme. ${ }^{20}$ Also, in Bologna, Emperor Frederick I Barbarossa issued the Authentica Habita or Privilegium Scholasticum in $1155^{21}$ to protect, among others, the right of foreign scholars to freedom of movement, security and their property.

Furthermore, in Germany (then Prussia), Alexander von Humboldt postulated the concepts of lernfreiheit (freedom to learn) and lehrfreiheit (freedom to teach) out of which evolved the special theory on academic freedom. ${ }^{22}$ Lernfreiheit gave students the freedom to choose the courses they want to follow and the university at which they want to study, thereby engaging in the cultivation of the self, a principle embodied in the notion of bildung (self-cultivation). ${ }^{23}$

\subsection{United States of America}

In the USA, influenced by the German experience, ${ }^{24}$ academic freedom found expression in the 1915 Declaration of the American Association of University Professors (AAUP) which, while it recognised the lehrfreiheit and lernfreiheit principles, ${ }^{25}$ did not elaborate on or directly recognise the rights of students.

The AAUP finally addressed this gap by drafting and adopting the 1967 Joint Statement on Rights and Freedoms of Students. The Preamble to the 1967 document recognises the inter-related and indivisible nature of academic freedom for academics and students thus, that 'the freedom to teach and the freedom to learn are inseparable facets of academic freedom'. ${ }^{26}$

Additionally, the courts have affirmed and recognised some kind of First Amendment right of academic freedom for students. In Sweezy $v$ New Hampshire, ${ }^{27}$ for instance, it was held that '[t]eachers and students must always remain free to inquire, to study and to evaluate, and to gain maturity and understanding; otherwise our civilization will stagnate and die'. Also, in Healy $v$ James $^{28}$ the court concluded that

20 T Karran 'Academic freedom: In justification of a universal ideal' (2009) 34 Studies in Higher Education 263.

21 De Ridder-Symoens (n 19).

22 JR Searle 'Two concepts of academic freedom' in EL Pincoffs (ed) The concept of academic freedom (1972) 86.

23 Metzger (n 4) 1304-1305.

$24 \mathrm{H}$ Röhrs The classical German concept of the university and its influence on higher education in the United States (1995).

25 Appendix I 1915 Declaration of Principles Academic Freedom and Academic Tenure at 292, http://www.aaup.org/NR/rdonlyres/A6520A9D-0A9A-47B3-B550C006B5B224E7/0/1915Declaration.pdf (accessed 7 January 2018).

26 Para 2 of the Preamble to Appendix C Joint Statement on Rights and Freedoms of Students (1967) reprinted with permission of the American Association of University Professors, from Policy Documents and Reports 141 (AAUP 1984).

$27 \quad 354$ US 234, 250 (1957).

28408 US 169, 181-82 (1972). 
respect for students' right to freedom of association was a reaffirmation of academic freedom.

\section{Dar es Salaam Declaration versus Kampala Declaration: What space for students?}

The first attempt by African scholars to develop a policy document to promote and protect academic freedom came in April 1990 when delegates from six academic staff associations of Tanzanian universities met in Dar es Salaam to proclaim the Dar es Salaam Declaration, 1990.

The Dar es Salaam Declaration contains some progressive provisions not only on academic freedom for universities and academics but also for students. It does so, among others, by adopting the term 'academic community' as used in the Lima Declaration to cover all three stakeholders in the academic freedom equation. ${ }^{29}$ Thus, there are numerous instances where, in respect of students and their rights to academic freedom, the document refers to the rights of all members of society to the academic community without hindrance; ${ }^{30}$ freedom of study; ${ }^{31}$ the right of participation in institutional governance; ${ }^{32}$ freedom of expression over national and international issues, individually and collectively; ${ }^{33}$ and the right to initiate, participate in and determine academic programmes of their institutions in accordance with the highest standards of education and the Basic Principles. ${ }^{34}$

Academics from the continent as a whole later met in Kampala, Uganda, in November 1990, to adopt the Kampala Declaration. However, unlike the Dar es Salaam Declaration, the Kampala Declaration does not seem to recognise students as forming part of the academic freedom matrix. Article 1 provides that '[e]very person has the right to education and participation in intellectual activity'. Since the right to education mainly covers students, one may argue that the numerous references to 'intellectuals' or the 'intellectual community' in the Kampala Declaration extend to students. However, academics are also entitled to enjoy or exercise the right to education, by reference to article $13(2)(\mathrm{e})$ of the International Covenant on Economic, Social and Cultural Rights (ICESCR): ${ }^{35}$

29 Para 53 of the Declaration which provides: 'In this Declaration, unless the context otherwise requires, "academic community" covers all those persons teaching, studying, researching or otherwise working at an institution of higher education.' The Declaration was made at the 68th General Assembly of World University Service, meeting in Lima, Peru, 6-10 September 1988.

30 Para 17 of the Declaration.

31 Para 23.

32 Paras $24 \& 39$.

33 Para 24.

34 Para 18. See also paras $14,25 \& 35$.

35 My emphasis. 
The States Parties to the present Covenant recognize that, with a view to achieving the full realization of this right ... (e) the development of a system of schools at all levels shall be actively pursued ... and the material conditions of teaching staff shall be continuously improved.

Thus, the Kampala Declaration uses 'African intellectuals' in a way that largely severs students from the academic freedom matrix. Where 'community' is used, the reference is not to 'academic community' but to 'intellectual community', such as in article 9 thereof, which does not extend in its meaning to cover students. Therefore, in terms of adopting an expansive approach to determine who the rights holders of the academic freedom matrix are, the Kampala Declaration is not a progressive document. Indeed, this Declaration gives direct recognition of students' rights to academic freedom in a single article, namely, article 7, which provides as follows:

Teaching and researching members of staff and students of institutions of education have the right, directly and through their elected representatives, to initiate, participate in and determine academic programmes of their institutions in accordance with the highest standards of education.

The only other direct mention of students in the Kampala Declaration is indicated with reference to the symposium the organisation of which culminated in the Kampala Declaration, which 'called for the transformation of administrative structures, procedures and practices in academic institutions to make these more representative of and accountable to teachers, researchers, students and others working within them'. ${ }^{36}$

\section{Inferring rights and freedoms for students from duties imposed on other duty bearers}

Apart from direct means of identifying rights and freedoms in the aforementioned documents, there are other indirect ways of doing the same; that is, by inferring these rights and freedoms from the duties imposed on the university and academics for the sake of their students. This approach is justified by the Hohfeldian principle that states that rights both confer a legal advantage (as 'claim rights') and impose correlative duties on any other person apart from the rights holder. In strict legal terms, correlativity such as this between a claim and a corresponding duty is the test of whether a legal stipulation is a 'right in the strict sense'.37

36 Under 'The intelligentsia and intellectual freedom' section of the Kampala Declaration.

37 W Hohfeld 'Some fundamental legal conceptions as applied in judicial reasoning' (1913) 23 Yale Law Journal 16, reprinted in W Hohfeld Some fundamental legal conceptions as applied in judicial reasoning and other legal essays (1923) 23 at 63-64. 
The relationship between rights and duties is acknowledged by the major international human rights instruments. For example, article 29 of the Universal Declaration of Human Rights (Universal Declaration) contains a general statement of principle regarding individual duties in international human rights law. Also, the Preambles to both the International Covenant on Civil and Political Rights (ICCPR) and ICESCR stipulate that 'the individual, hav[e] duties to other individuals and to the community to which he belongs, is under a responsibility to strive for the promotion and observance of ... rights'.

However, a careful examination of the Kampala Declaration reveals that under the 'Responsibilities' section, none of the responsibilities spelt out which can be converted into a right directly address students based on the above formula. The only exception is article 19, which provides that ' $[\mathrm{m}]$ embers of the intellectual community are obliged to discharge their roles and functions with competence, integrity and to the best of their abilities. They should perform their duties in accordance with ethical and highest scientific standards.'

The sidelining of students in the Kampala Declaration is unfortunate, considering the fact that one of the motives for the adoption of the Kampala Declaration was to counter the excesses of the International Monetary Fund and the World Bank's structural adjustment policies which severely affected respect for the academic freedom of not only academics but also universities and students in Africa. ${ }^{38}$ Thus, a Human Rights Watch report on academic freedom in Africa in the 1980s noted violations of human rights on African campuses which affected students directly and indirectly: ${ }^{39}$

[S] ummary executions of students; torture; arbitrary arrest and prolonged detention without charge or trial; imprisonment under conditions that are cruel and degrading; restrictions on freedom of expression, assembly, association and movement; dismissal of faculty staff; expulsion of students; university closures; banning of student organizations and staff unions; the prohibition of 'political activity' on campus; discrimination against students on the basis of race, ethnic or regional origin; censorship of teaching and reading materials and manipulation of curricula; refusal to grant scholarships to politically active students; and the requirement that students who have been implicated in political disturbances sign pledges of 'good behaviour' in order to resume their studies ... Students and academics were paid to inform on each other.

38 See, eg, para 1 of the Preamble to the Kampala Declaration: 'Intellectual freedom in Africa is currently threatened to an unprecedented degree. The historically produced and persistent economic, political and social crisis of our continent continues to undermine development in all spheres. The imposition of unpopular structural adjustment programmes has been accompanied by increased political repression, widespread poverty and intense human suffering.'

39 Human Rights Watch Academic freedom and human rights abuses in Africa (Africa Watch Report, March 1991). 
Applying the same formula of deriving rights from duties to the 1966 ILO/UNESCO Recommendation and the 1997 UNESCO Recommendation, ${ }^{40}$ however, one is able to identify several rights and freedoms indirectly carved out for students based on the duties the UNESCO Recommendation imposes on the state, the university and academics. Students' academic freedom vis-à-vis the state includes the protection of their right to education; the right to demand respect for institutional autonomy for the university; as well as respect for institutional self-governance, tenure and academic freedom for academics. ${ }^{41}$

With respect to students' academic freedom vis-à-vis the university, the following are discernible: the right of access to library facilities and modern teaching, research and information resources; ${ }^{42}$ the right to quality and excellence in the teaching, scholarship and research functions of the university; ${ }^{43}$ the right to fair and just treatment, without discrimination based on sex, nationality and racial status; 44 the right to take part in culture and to enjoy the benefits of scientific progress and its applications within and outside the confines of the university; and the right to participate in university governance. ${ }^{45}$

Students' academic freedom vis-à-vis academics includes the right to be taught effectively according to accepted professional principles and norms; the right to a free exchange of ideas between academics and students; ${ }^{46}$ the right of access to guidance in their studies; ${ }^{47}$ the right to acknowledgment of scholarly work; ${ }^{48}$ the right to express their views on (and contribute to the development of) the content of curricula; the right to participate in university governance; and the right to criticise the university and academics and to demand accountability from the institution and individual lecturers. ${ }^{49}$

401997 UNESCO Recommendation Concerning the Status of Higher Education Teaching Personnel in Records of the General Conference: 29th Session, Paris, 21 October to 12 November 1997, Vol 1, Resolutions (Paris: UNESCO 1997) para 74. The 1966 ILO/UNESCO Recommendation was adopted on 5 October 1966 at a conference held in Paris at UNESCO headquarters and organised in close cooperation with the ILO.

41 Paras 17-21 of the 1997 UNESCO Recommendation.

42 Para 22(o) ILO/UNESCO Recommendation.

43 Paras 22(b) \& (d).

44 Paras 22(f) \& (g) \& para 34.

45 Para 17.

46 Para 34.

47 As above.

48 As above.

49 Para 22 of the ILO/UNESCO Recommendation. 


\section{Students' academic freedom, the right to education and democratic enhancement}

Students' academic freedom is linked to the right to education. ${ }^{50}$ In the General Comment under article 13 of ICESCR, the ESCR Committee noted that 'the right to education can only be enjoyed if accompanied by academic freedom of staff and students'. The Kampala Declaration confirms this in article 1 thereof.

Various international instruments express the vital relevance of education as a tool for the promotion of human rights, peace and democracy in the world. Among these is the Universal Declaration. Article 26(2) of the Universal Declaration provides:

Education shall be directed to the full development of the human personality and to the strengthening of respect for human rights and fundamental freedoms. It shall promote understanding, tolerance and friendship among all nations, racial or religious groups, and shall further the activities of the United Nations for the maintenance of peace.

Following its adoption, the UN General Assembly proclaimed the Universal Declaration as 'a common standard of achievement for all peoples and all nations, to the end that every individual and every organ of society, keeping this Declaration constantly in mind, shall strive by teaching and education to promote respect for these rights and freedoms'. Due to the fundamental relevance and cardinal importance of education for peace, justice, democracy and human rights, article 13 of ICESCR repeats verbatim the provision in article 26(2) of the Universal Declaration quoted above.

Thus, academic freedom is meant to promote the enjoyment of the right to education which in turn will help in the use of education to promote human rights, democracy, justice and the rule of law. Consequently, the best way in which the right to education can be applied effectively is when an environment is put in place which is conducive to students enjoying their academic freedom.

Indeed, academic freedom and democracy are not far removed from each other. They enjoy a mutually reinforcing relationship: Academic freedom engenders or supports democracy (at the university and in society) and the other way round.

First, academic freedom is designed to promote democracy on the university campus. Thus, for example, article 20 of the Kampala Declaration stipulates that '[m]embers of the intellectual community have a responsibility to promote the spirit of tolerance towards different views and positions and enhance democratic debate and discussion'. The same document also 'called for the promotion of participatory and democratic methods of teaching, research and

50 Beiter (n 15) 5. See also KD Beiter The protection of the right to education by international law (2006). See a contrary view in De Baets (n 15) 2-3. For a critique of both approaches, see Appiagyei-Atua (n 15). 
publishing, and high professional and ethical standards'. In practice, a pluralistic approach of encouraging students to exercise judgment in their choice of perspective within the discipline supports democratic relationships. Another is the emphasis placed on the value of students having some element of choice in the teaching methods used. The application of these democratic principles has the tendency to produce a spin-off effect in the larger society when students graduate and carry the practice of democracy with them.

Second, academic freedom is a tool to promote democracy in the larger society. That is, the existence of the space for the enjoyment and exercise of academic freedom can provide the opportunity to expand that space to benefit the society at large in the context of the struggle for human rights and democracy. That is, academics are supposed to utilise their privileged positions to support democracy in society and promote a close relationship between academia and society ('gown-town' relationship). Thus, the Kampala Declaration sets the standard as a useful reference point that the struggle for academic freedom is an integral part of the general struggle for human rights and democracy. ${ }^{51}$

In most African countries students have also played their role in extending the enjoyment of academic freedom beyond the confines of the university space to the streets in support of larger freedoms. For example, during the clamour to return to democracy after the fall of the Berlin Wall, students took an active part in the process, relying on the freedoms of expression, association and assembly, among other freedoms, which they began to assert and exercise on university campuses. $^{52}$ The Kampala Declaration unfortunately failed to recognise the role of students in using academic freedom to promote democracy and human rights on the university campuses as well as in the society at large.

The application of these rights and freedoms for students is tested against the enjoyment of academic freedom for students at the University of Ghana, Legon.

\section{Students' academic freedom at the University of Ghana}

Ghana is counted among 14 African countries of which the constitutions contain specific recognition of academic freedom. Ghana is also recognised as one of nine African countries categorised as 'free' with respect to the level of respect for academic freedom in

51 Appiagyei-Atua, Bieter \& Karran (n 11).

52 C Mawuko-Yevugah 'From resistance to acquiescence? Neoliberal reform, student activism and political change in Ghana' (2013) 8 Postcolonial Text 1 at 12 13. Also, D Finlay 'Students and politics in Ghana' (1968) 97 Daedalus 51. 
its laws. ${ }^{53}$ Focusing on students' academic freedom, Ghana's laws seeking to protect and promote students' rights generally are progressive. Students are recognised as forming part of an academic community and are consequently protected against acts or omissions that exceed the bounds of freedom of expression or academic freedom, including, but not restricted to, those explicitly adopted. ${ }^{54}$ Also, discrimination on the grounds of nationality, race, caste, religion, place of origin, political opinions, colour, creed or sex is prohibited in determining admission, registration or graduation of a student of the University, or to hold any advantage or privilege thereof. ${ }^{55}$ Further, the Office of the Dean of Student Affairs is to take charge of the counselling and placement of students; the provision of chaplaincy services; the resolution of conflicts among students, and so forth. ${ }^{56}$ One may also refer to section 10(4) of the University of Ghana Act in terms of which some of the functions of the Office of the Registrar include providing support and information to all staff and students, including financial support to students, student progress and completions, student discipline and student complaints.

In addition, students are engaged in university governance in various ways through their Students' Representative Council (SRC) (for undergraduate students) facilitating SRC's representation on appropriate bodies and organs of the University. ${ }^{57}$ Consequently, students are represented on various boards, committees and other bodies, prominent among which are representation on the University Council; 58 the Board of Nominators to elect a Chancellor; 59 boards of faculties; ${ }^{60}$ the Court; ${ }^{61}$ Senate; ${ }^{62}$ the Council; ${ }^{63}$ the student disciplinary board; ${ }^{64}$ the tutorial board; 65 and the advisory board for the Dean of Student Affairs. ${ }^{66}$ Similar rights and privileges are granted to graduate students through their association, the Graduate Students Association of Ghana (GRASAG).

Also, disciplinary issues are handled through the student disciplinary board with a right of appeal to the University of Ghana

53 K Appiagyei-Atua, KD Beiter \& T Karran 'A review of academic freedom in Africa through the prism of the UNESCO's 1997 Recommendation' (2016) 14 Journal of Higher Education in Africa/Revue de l'Enseignment Supérieur en Afrique 85.

54 Sec 42(1)(iii) Statutes of the University of Ghana, 2011.

55 Sec 29(1).

56 Sec 38(2).

57 Sec 38.

58 Sec 11.

$59 \operatorname{Sec} 3(3)$.

60 Secs 28(8) \& 25.

61 Sec 19.

62 Sec 23.

63 Sec 20.

64 Sec 43(7).

65 Sec 40(8).

66 Sec 38(5). 
Appeals Board, an independent dispute resolution body set up under section 44 of the University Statute.

Academics are enjoined to respect students' academic freedom by making conscious efforts to refrain from promoting any political, religious, racial or ethnic ideology in class. ${ }^{67}$ They are also to refrain from any type of harassment or discrimination against students, ${ }^{68}$ and should ensure that their relationships with students do not develop in ways that can undermine objectivity in grading, evaluation or assessment. ${ }^{69}$

However, there equally are some provisions in the University of Ghana Act that raise questions as, in principle, they violate academic freedom or are likely to infringe on academic freedom in practice. These include a situation where the Dean of Student Affairs is given the power to grant permission to students before they may join protest marches and demonstrations, within or outside the University. This provision clearly contravenes the decision of the Supreme Court in the NPP $\vee$ IGP case $^{70}$ in which it was held that demonstrators do not need to ask for permission from the police before they can exercise their right to freedom of assembly. They are only expected to inform the police. This decision culminated in the enactment of the Public Order Act 491 of 1994.

As well, section 37(5) of the University of Ghana Act gives the ViceChancellor, in consultation with the Academic Board, the power to prescribe standards for contesting student offices. Based on this, students whose average grades fall below a certain mark are barred from contesting student political offices. This stipulation also violates the constitutional right of every citizen to contest political office without discrimination of any kind. ${ }^{71}$

Apart from the limitations mentioned above, actualising the positive references in the law seeking to promote and protect academic freedom for students at the University of Ghana presents challenges for students. While the abuses suffered directly from the state in the past have abated in most cases or have become subtler and more indirect, the university management and academics remain the dominant violators of the duties they owe to students.

One of the key issues affecting university/student relations and academic/student relations is the power dynamic which remains largely tilted in favour of the University and the academic as against the student. Therefore, the University and academics are able to apply fear tactics to intimidate students on campus. While the University and academics are able to apply swift sanctions against a student, the

67 'Code of conduct for academic staff of the University of Ghana' (2011) 49 University of Ghana Special Reporter 1.6.2.

68 Code of Conduct (n 65) para 10.1.

69 Para 10.2.

70 [1992-93] GLR 586.

71 Art 421992 Constitution of the Republic of Ghana. 
student has limited opportunities, most often involving a complicated process to launch complaints which may take sometimes or year or more to resolve. During this period when students are not sure of the outcome of the complaint, they are left in suspense which is likely to have a negative impact on their studies.

Students are also afraid of reprisals by academics against them should they report academics to authorities. This situation is aggravated by the fact that in most disciplinary processes, the same academics administer the processes. There are situations where reports have been leaked to alleged perpetrators who in turn have reinforced their harassment against the complaining student to abort the process or be threatened with other negative consequences, such as failure in a paper. Therefore, students lack trust in such mechanisms to resolve their complaints against their lecturers and professors. Some student representative councils are also co-opted or have weak bargaining powers to advocate students' rights and to seek representation for abused students. Thus, at the end of the day, students accept the status quo ante as the norm.

\section{Conclusion}

Students are among the primary recipients and users of the knowledge produced by academics. They are also the conduit through which knowledge is channelled to society. Therefore, they cannot be left out of the academic freedom equation.

Because of the inter-related and interdependent nature of the elements of academic freedom, where a particular beneficiary's rights are ignored, the other entities are not able to fully enjoy their rights, and society, the ultimate beneficiaries of the enjoyment of academic freedom, turn out to be the biggest losers.

The article concludes that the suppression of students' right to academic freedom has denied many students the right and opportunity to have a democratic engagement and involvement in the conduct of university affairs and in the way in which knowledge is produced and shared. The practice of this non-democratic engagement between the university and academics, on the one hand, and students, on the other, is the norm for some students. They consequently leave the confines of the university after graduation with a questionable understanding of democracy and human rights which subsequently informs their behaviour in their communities, work place as well as in politics. In the end, the lack of democratic engagement with students occasioned by the denial of their academic freedom tends to have a negative impact on the democratic programme in Africa.

Therefore, promoting students' rights and knowledge-sharing on African university campuses will imbibe in the students a respect for 
democracy, human rights and the rule of law which they will carry with them from the university into society. 